\title{
AquaPathogen X: A Template Database for Tracking Field Isolates of Aquatic Pathogens
}

AquaPathogen $X$ is a template database for recording information on individual isolates of aquatic pathogens and is available for download from the U.S. Geological Survey (USGS) Western Fisheries Research Center (WFRC) website (http://wfrc.usgs.gov). This template database can accommodate the nucleotide sequence data generated in molecular epidemiological studies along with the myriad of abiotic and biotic traits associated with isolates of various pathogens (for example, viruses, parasites, or bacteria) from multiple aquatic animal host species (for example, fish, shellfish, or shrimp). The simultaneous cataloging of isolates from different aquatic pathogens is a unique feature to the AquaPathogen $X$ database, which can be used in surveillance of emerging aquatic animal diseases and clarification of main risk factors associated with pathogen incursions into new water systems. As a template database, the data fields are empty upon download and can be modified to user specifications. For example, an application of the template database that stores the epidemiological profiles of fish virus isolates, called Fish ViroTrak (fig. 1), was also developed (Emmenegger and others, 2011).

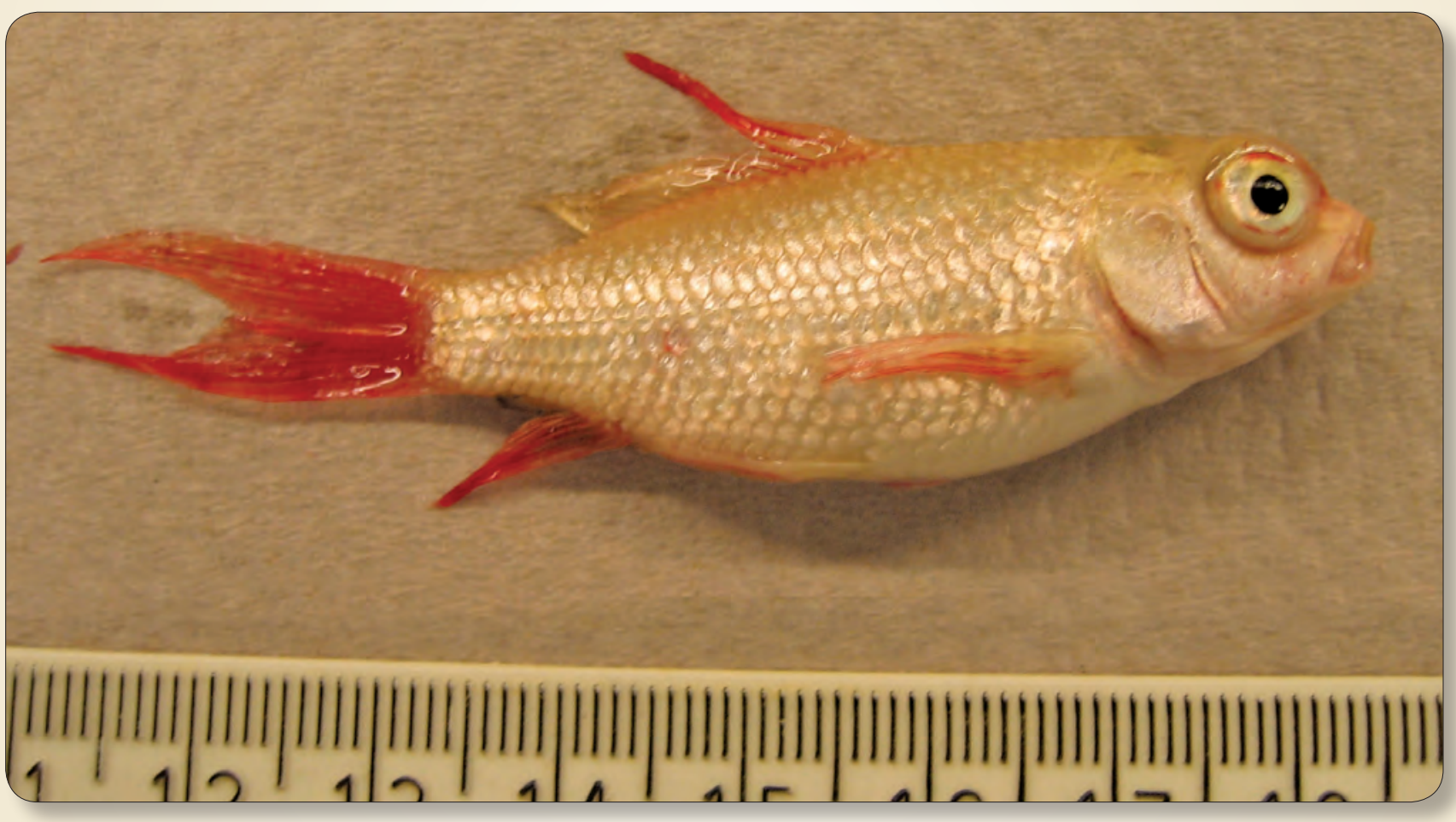

Koi (Cyprinus carpio kol) infected with an exotic fish virus (spring viremia carp virus) emerging in North America. This fish is exhibiting typical clinical signs of disease, hemorrhaging in all fins and pop-eye.

In recent years, the emergence of aquatic pathogens in North America has escalated, particularly for fish rhabdoviruses (Goodwin, 2002; Elsayed and others, 2006; Garver, and others, 2006). Increased numbers of disease outbreaks have occurred in wild, food-based aquaculture, and ornamental fish stocks. Global fish trade, increased aquaculture production, pathogen evolution, and climate change have been suggested as possible reasons for the rising prevalence of viral aquatic pathogens and ensuing epidemics (Walker and Winton, 2010).
To assess these possible hypotheses, monitoring of the emerging pathogens is required. As the number of aquatic pathogen incidences increases, it is especially important to catalog the epidemiological data associated with each pathogen isolate in order to perform disease risk analyses and discern disease patterns. Proper surveillance and assessment of pathogen incursions also requires consistent data parameters for making valid science-based analyses to support sanitation orders and validate the implementation of disease control policies. 

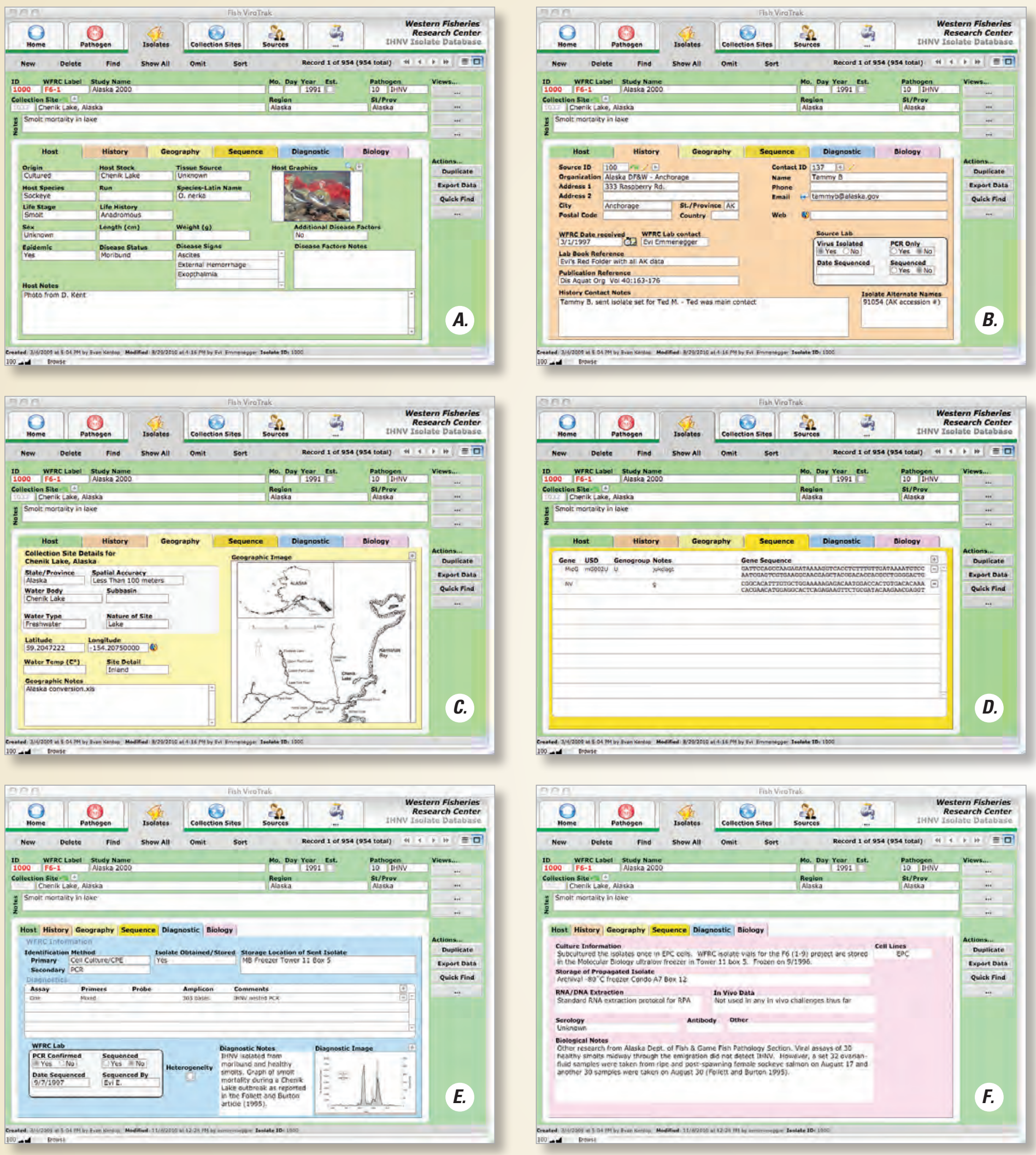

Figure 1. Screen captures of data category windows cataloging information for each virus isolate record in the Fish ViroTrak database that include: general pathogen information (continuously displayed at the top of each window); $(A)$ host background; $(B)$ isolate history; $(C)$ geographic/spatial data; $(D)$ gene sequences; $(E)$ diagnostics; and $(F)$ biological factors. The sequence field in panel $(D)$ expands upon selection to view any input length of nucleotide sequence. The example epidemiological data displayed in the panels are from an infectious hematopoietic necrosis virus (IHNV) isolate sampled during an epidemic in sockeye salmon at an aquaculture facility in Alaska. 


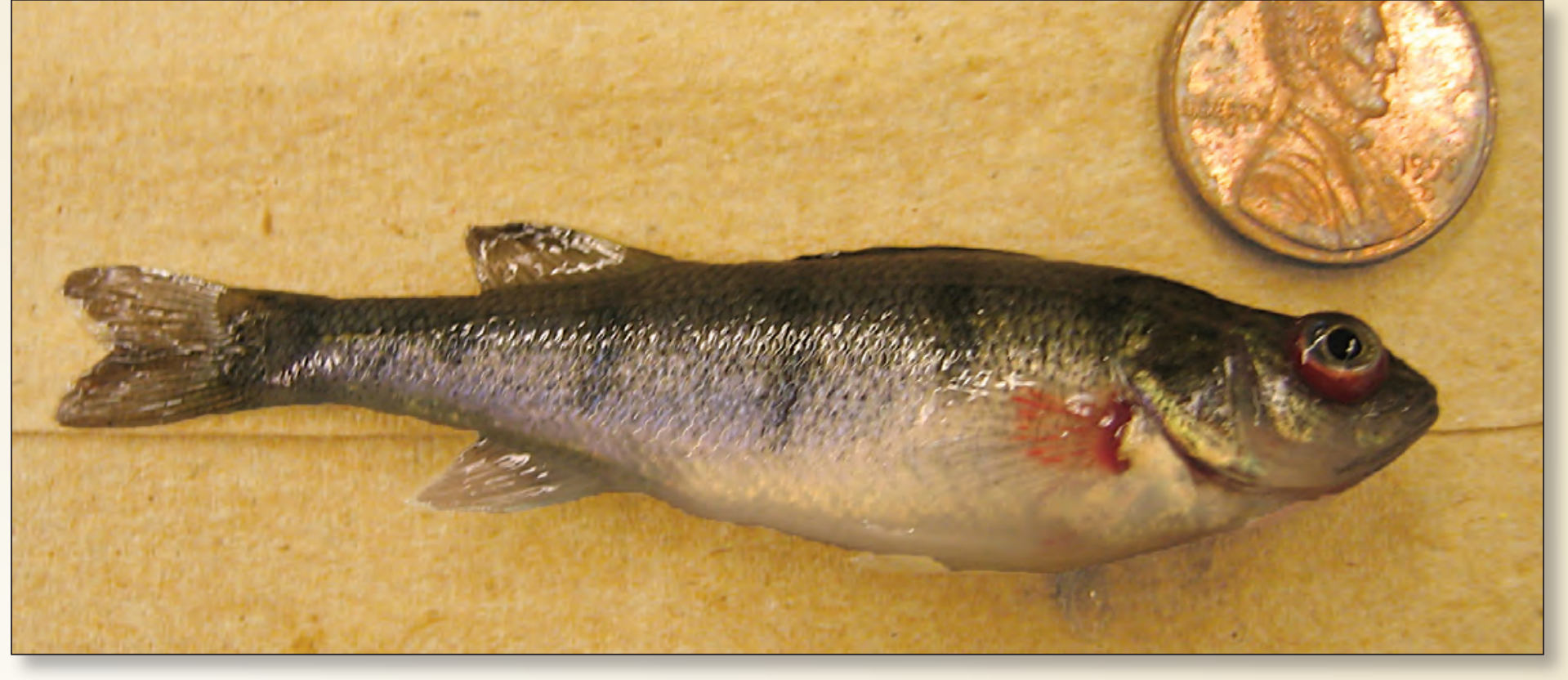

Viral hemorrhagic septicemia virus (strain IVb), is an invasive fish virus emerging in the Great Lakes region. This yellow perch (Perca flavescens) is showing evidence of disease (for example, hemorrhaging in the eye and bleeding in a pectoral fin) after exposure to this virus

Collating accurate and comprehensive aquatic disease information into a computer-based cataloging system is vital to the development of an aquatic pathogen-monitoring program. General aquatic animal disease databases provide accurate overviews of pathogen features, including host specificity, confirmatory diagnostic tests, countries of occurrence, and bibliographies of the listed aquatic animal pathogens, and can be used to document the initial introduction of a pathogen into a new country. The databases do not catalog subsequent incidences of the pathogen, which is needed to monitor the emergence of a novel pathogen, or track the spread of an established pathogen. Researchers attempting to discern disease patterns, or resource managers making critical sanitation decisions at infected sites, require detailed epidemiological information of the aquatic pathogen isolates, such as a georeferenced isolation site, genetic type, gene sequences, water systems, or host stocks (table 1), to accomplish these tasks.

Table 1. Primary data categories and associated epidemiological information fields available to catalog each pathogen isolate in the AquaPathogen $\mathrm{X}$ database.

\begin{tabular}{|c|c|}
\hline \multicolumn{1}{|c|}{ Categories } & \multicolumn{1}{c|}{ Information fields } \\
\hline General Host & $\begin{array}{l}\text { Pathogen, In-house label, Record number, Date collected, Collection site origin, Host stock, Run, Tissue, } \\
\text { Host species common name, Species Latin name, Life stage, Sex, Life history, Length, Weight, Epidemic, } \\
\text { Disease status, Disease signs, Host graphics }\end{array}$ \\
\hline History & $\begin{array}{l}\text { Source organization, Source contact name, Date received, In-house laboratory contact, In-house laboratory } \\
\text { notebook reference, Source laboratory collection information (such as PCR only or pathogen isolated) }\end{array}$ \\
\hline Geography & $\begin{array}{l}\text { Collection site, State/Province, Water body, Subbasin, Water type, Nature of site (farm, hatchery, spawning } \\
\text { channel, or wild), Latitude, Longitude, Spatial accuracy, Water temperature, Site detail, Site graphic }\end{array}$ \\
\hline Diagnostic & $\begin{array}{l}\text { Gene region(s) sequenced, Nucleotide sequences, Genogroups, Universal sequence designator (USD) } \\
\text { assay primers or probes), Storage location of original isolate, In-house confirmation (such as PCR or } \\
\text { sequencing), Images }\end{array}$ \\
\hline Biology & $\begin{array}{c}\text { Cell culture, Cell lines, RNA/DNA extraction, In vivo data, storage of cultured isolate, serology, } \\
\text { antibody reactivity }\end{array}$ \\
\hline
\end{tabular}

\section{Development of Template Database: AquaPathogen X}

The AquaPathogen $\mathrm{X}$ template database was built using FileMaker® Pro, Inc. (2011) (http://www.filemaker.com), a cross-platform user oriented database application. This platform was selected because it has an easy learning curve for a user to customize the application for specific purposes; support is available in 60 countries and 11 languages; it is scalable from single user to multi-user operation; it is a server-based operation 
with no modification of the AquaPathogen X database; it supports simultaneous Macintosh ${ }^{\circledR}$ and Windows ${ }^{\circledR}$ users in multi-user environment; and it has a fully relational database with open database connectivity (ODBC) capabilities, if required. The database has standard navigation buttons, or the built-in FileMaker Pro keyboard commands and shortcuts. The FileMaker Pro application has built-in features to allow for a wide range of users to modify and customize the database. The template database is distributed with all user and development passwords, which can be customized by the site manager. The AquaPathogen $\mathrm{X}$ database currently runs on FileMaker Pro, version 9.0.

\section{Application of Database Template: Fish ViroTrak}

At the WFRC, the AquaPathogen X template was used to develop a catalog of fish viral pathogens called Fish ViroTrak. Currently, Fish ViroTrak catalogs isolate data for three aquatic rhabdovirus species, infectious hematopoietic necrosis virus (IHNV), viral hemorrhagic septicemia virus (VHSV), and spring viremia of carp virus (SVCV). For every isolate record, 77 data items are collected and organized into 7 categories: general pathogen information, host background, isolate history, geographic/spatial data, gene sequences, diagnostics, and biological factors (fig. 1). Each category provides several data fields to record specific features associated with a pathogen isolate (table 1).

\section{Database Usage}

Any of the epidemiological factors listed in the database can be queried. A navigation page containing the most common search parameters, such as gene sequences, host species, isolation locations, and year of isolation, also is available for rapid database inquiries. Genetic sequence queries can identify identical matches; therefore, molecular identification of pathogen strain type is easily achieved. New genetic types, that may have phenotypic differences, also are quickly discovered. Database mining can be single or multifactorial key word searches (for example, rainbow trout and VHSV G gene nucleotide sequence and Great Lakes). Search results are displayed in various table or report formats. Additional predefined sort options based on user needs are available, as well as customized search and sort options.

The practical application of the Fish ViroTrak and template AquaPathogen $\mathrm{X}$ databases is the organization of copious amounts of data associated with pathogen detections, including gene sequences. Aquatic animal health researchers and resource agencies can customize the template as an in-house database to catalog their own aquatic pathogen isolates. AquaPathogen $\mathrm{X}$ template database can become a widely distributed resource for expediting the collation and comparisons of emerging aquatic pathogens.

\section{References Cited}

Elsayed, E., Faisal, M., Thomas, M., Whelan, G., Batts, W., and Winton, J., 2006, Isolation of viral haemorrhagic septicaemia virus from muskellunge, Esox masquinongy (Mitchill), in Lake St. Clair, Michigan, USA reveals a new sublineage of the North American genotype: Journal of Fish Diseases, no. 29, p. 611-619.

Emmenegger, E., Kentop, E., Thompson, T., Pittam, S., Ryan, A., Keon, D., Carlino, J., Ranson, J., Life, R., Troyer, R., Garver, K., and Kurath, G., 2011, Development of an aquatic pathogen database (AquaPathogen X) and its utilization in tracking emerging fish virus pathogens in North America: Journal of Fish Diseases, no. 34, p. 579-587.

FileMaker, Inc., 2011, Database software, FileMaker Pro ver. 9.0: FileMaker, Inc., website, accessed October 20, 2011, at http://www.filemaker.com/.

Garver, K.A., Batts, W.N., and Kurath, G., 2006, Virulence comparisons of infectious hematopoietic necrosis virus $U$ and $\mathrm{M}$ genogroups in Sockeye salmon and rainbow trout: Journal of Aquatic Animal Health, no. 18. p. 232-243.

Goodwin, A.E., 2002, First report of spring viremia of carp virus (SVCV) in North America: Journal of Aquatic Animal Health, no. 14, p. 161-164.

Walker, P.J., and Winton, J.R., 2010, Emerging viral diseases of fish and shrimp: Veterinary Research, no. 24 p. 51.

A complete list of WFRC publications is available at http://wfrc. usgs.gov/cgi-bin/pub search.cgi?0\&view=all.

Photograph credits: All photographs by Evi Emmenegger.

Authors: Evi Emmenegger and Gael Kurath

\section{For Information Contact:}

Director, Western Fisheries Research Center U.S. Geological Survey 6505 NE 65th Street Seattle, WA 98115 Ph: (206) 526-6282 FX: (206) 526-6654

Email: wfrc@usgs.gov $\underline{\text { http://wfrc.usgs.gov/ }}$

Any use of trade names is for descriptive purposes only and does not imply endorsement by the U.S. Government.

Publishing support provided by the

U.S. Geological Survey

Tacoma Publishing Service Center 